\title{
Prevalence of Endodontically Treated Teeth in a Brazilian Adult Population
}

\author{
Augusto César Braz HOLLANDA ${ }^{1}$ \\ Ana Helena Gonçalves de ALENCAR ${ }^{1}$ \\ Cyntia Rodrigues de Araújo ESTRELA ${ }^{1}$ \\ Mike Reis BUENO ${ }^{2}$ \\ Carlos ESTRELA ${ }^{1}$ \\ ${ }^{1}$ Dental School, Federal University of Goiás, Goiânia, GO, Brazil \\ ${ }^{2}$ Dental School, University of Cuiabá, Cuiabá, MT, Brazil
}

\begin{abstract}
This cross-sectional study examined the prevalence of endodontically treated teeth in 1,401 Brazilian adults. Panoramic radiographs were selected at the Radiological Center of Orofacial Images (CRIOF, Cuiabá, MT, Brazil) between August 2002 and September 2007. Three independent endodontists discussed interpretation criteria and classified specimens according to the following data: presence of root canal treatment, which was defined as partially or completely filled canal space, regardless of whether filling ended at the radiographic apex or not; presence of intracanal post; and associated apical periodontitis. Odds ratio, logistic regression and a chi-square test were used for statistical analyses. Significance level was set at $\mathrm{p}<0.05$. Of 29,467 teeth evaluated, 6,313 (21.4\%) were treated endodontically. Endodontic treatment was most frequent in maxillary premolars and molars, whereas mandibular incisors showed the lowest prevalence. Most endodontically treated teeth were found in people aged 46 to 60 years $(47.6 \%$, p $<0.001)$ and the prevalence increased with age in this age range. Females $(61.9 \%, p<0.001)$ showed a higher prevalence of teeth with root fillings than males. The present study found a higher prevalence of endodontically treated teeth in a Brazilian adult population compared to the prevalence reported in epidemiological studies conducted in other countries.
\end{abstract}

Key Words: apical periodontitis, endodontic treatment, root canal filling, endodontic epidemiology, epidemiology.

\section{INTRODUCTION}

Several risk factors may affect the dental pulp. One of the most important injurious agents of the dental pulp is caries disease, caused by oral microorganisms. Pulp infection is an important caries sequel and the endodontic treatment should be planned according to disease prevalence. The study of endodontic epidemiology may contribute to increase this knowledge.

Previous studies have investigated the mechanisms of microbial aggression to the dental pulp, the development of apical periodontitis (AP), and treatments for pulp injuries $(1,2)$. However, some factors may affect tooth survival, such as dental caries, periodontal disease and endodontic treatment. Dental caries causes some of the most severe injuries to the dental pulp. A report on the oral health of the Brazilian population between 2002-2003, issued by the Brazilian Ministry of Health (3), showed that $70 \%$ of the 12 -year-old and $90 \%$ of the 15-19-year-old adolescents had at least one decayed tooth. Individuals aged 35 to 44 and 65 to 74 years show a substantial increase in the number of dental caries sequelae.

The prevalence of endodontically treated teeth associated with AP or not has been examined in several populations (4-14). Some epidemiological studies evaluated the total number of treated teeth, while others evaluated the number of individuals with endodontic treatment and the association of endodontic treatment with AP (7-15). Data of theses studies showed that $1.2 \%$ to $23 \%$ of all teeth had endodontic treatment. Tsuneishi et al. (7) evaluated the prevalence of endodon- 
tic treatment and periapical radiolucencies in a Japanese adult population. Periapical status and length of root fillings of 672 adult patients seen at the Okayama University Hospital of Dentistry were evaluated using full-mouth intraoral radiographs. The total number of examined teeth was 16,232 , and 3,320 teeth $(20.5 \%)$ had been treated endodontically. The prevalence of root-filled teeth was higher in this Japanese population than in Europe or America $(9-11,15,16,18)$. However, the ratio of teeth with apical radiolucency in root-filled teeth was within the range reported for other countries. Bueno and Estrela (19) examined the prevalence of endodontic treatment and AP in different populations using a systematic review. Their search yielded 262 studies and 63 met their inclusion criteria. The prevalence of AP in association with endodontic treatment was high. There was a discrepancy between minimum and maximum prevalence rates. These indexes are important evaluation tools and show that continuous scientific updating is necessary.

Eriksen et al. (4) have pointed that the purposes of the few epidemiological studies in Endodontics published in the last decade were the adjustment of preventive and clinical procedures and the determination of endodontic treatment status.

According to the Brazilian Ministry of Health (3), data on the prevalence of dental caries in Brazil and the scarcity of epidemiological studies indicate that the prevalence of endodontic treatment should be investi- gated. Therefore, the purpose of this study was to examine the prevalence of endodontically treated teeth in a Brazilian adult population.

\section{MATERIAL AND METHODS}

This cross-sectional study examined the prevalence of endodontically treated teeth in 1,401 males and females with a mean age of 48 years. Panoramic radiographs were retrieved from randomly selected charts of patients seen at the Radiological Center of Orofacial Images (CRIOF, Cuiabá, MT, Brazil) between August 2002 and September 2007. The sample consisted of 1,401 panoramic images captured with an Orthoralix 9200 AEC panoramic system (Gendex Dental Systems, Des Plaines, IL, USA) using 0.5-mm focal spot and Kodak dental film (T-MAT, 15X30, Manaus, AM, Brazil). The study protocol was independently reviewed and approved by the institutional Research Ethics Committee.

Three independent endodontists with over 5 years of clinical experience discussed interpretation criteria and then examined the radiographs. About 10\% of all samples were initially examined by the observers for calibration and standardization of evaluation criteria. When a consensus was not reached after two observers examined the radiographs, the third observer made the final decision. The images were examined using an image-analysis software (Planimp software, CRIOF,

Table 1. Prevalence of endodontic treatment according to gender and age.

\begin{tabular}{|c|c|c|c|c|c|c|c|c|c|c|c|}
\hline & \multicolumn{3}{|c|}{ No endodontic treatment } & \multicolumn{3}{|c|}{ Endodontic treatment } & \multirow{2}{*}{$\mathrm{P} 1$} & \multirow{2}{*}{$\mathrm{P} 2$} & \multirow{2}{*}{ OR } & \multicolumn{2}{|c|}{ OR $(95 \% \mathrm{CI})$} \\
\hline & $\mathrm{n}^{1}$ & $\mathrm{n}^{2}=23,154$ & $\mathrm{~N}=29,467$ & $\mathrm{n}^{1}$ & $\mathrm{n}^{2}=6,313$ & $\mathrm{~N}=29,467$ & & & & Min & Max \\
\hline Females & 13,440 & $58.0 \%$ & $45.6 \%$ & 3,906 & $61.9 \%$ & $13.3 \%$ & & & & & \\
\hline Males & 9,714 & $42.0 \%$ & $33.0 \%$ & 2,407 & $38.1 \%$ & $8.2 \%$ & $<0.001$ & $<0.001$ & 0.853 & 0.805 & 0.903 \\
\hline Total & 23,154 & $100.0 \%$ & $78.6 \%$ & 6,313 & $100.0 \%$ & $21.4 \%$ & & & & & \\
\hline$<30$ yrs & 3,536 & $15.3 \%$ & $12.0 \%$ & 214 & $3.4 \%$ & $0.7 \%$ & & & & & \\
\hline $31-45$ yrs & 8,478 & $36.6 \%$ & $28.8 \%$ & 1,793 & $28.4 \%$ & $6.1 \%$ & & & & & \\
\hline $46-60 \mathrm{yrs}$ & 8,460 & $36.5 \%$ & $28.7 \%$ & 3,005 & $47.6 \%$ & $10.2 \%$ & $<0.001$ & $<0.001$ & 1.743 & 1.685 & 1.802 \\
\hline$>60 \mathrm{yrs}$ & 2,680 & $11.6 \%$ & $9.1 \%$ & 1,301 & $20.6 \%$ & $4.4 \%$ & & & & & \\
\hline Total & 23,154 & $100.0 \%$ & $78.6 \%$ & 6,313 & $100.0 \%$ & $21.4 \%$ & & & & & \\
\hline
\end{tabular}

$\mathrm{n}^{1}=$ number of each tooth type; $\mathrm{n}^{2}=$ number of teeth without endodontic treatment; $\mathrm{N}=$ total number of teeth; $\mathrm{P} 1=\chi^{2} ; \mathrm{P} 2=$ logistic regression; OR - odds ratio; $\mathrm{Min}=$ minimum; $\mathrm{Max}=$ maximum. 
Cuiabá, MT, Brazil) in a PC workstation running Microsoft Windows XP professional SP-1 (Microsoft Corp., Redmond, WA, USA).

The criteria for radiographic detection of endodontic treatment of all teeth seen on the radiographs, except for third molars, were the presence of radiopaque material in the pulp chamber, in one or more root canals, or in a combination of these sites. The following conditions were recorded: poor or complete root canal filling, ending or not at the radiographic apex or not, presence of intracanal post and associated AP.
Odds ratio, logistic regression and a chi-square test were used for statistical analyses. Significance level was set at $p<0.05$. Interobserver agreement was assessed using kappa (k) values.

\section{RESULTS}

Of 29,467 evaluated teeth, 6,313 (21.4\%) had been endodontically treated. Table 1 shows the distribution of endodontically treated teeth according to age and gender. Table 2 shows the prevalence and distribution

Table 2. Prevalence of endodontic treatment according to dental group.

\begin{tabular}{|c|c|c|c|c|c|c|c|c|c|c|c|}
\hline \multirow[t]{2}{*}{ Tooth } & \multicolumn{3}{|c|}{ No endodontic treatment } & \multicolumn{3}{|c|}{ Endodontic treatment } & \multirow{2}{*}{$\mathrm{P} 1$} & \multirow{2}{*}{$\mathrm{P} 2$} & \multirow{2}{*}{ OR } & \multicolumn{2}{|c|}{ OR $(95 \% \mathrm{CI})$} \\
\hline & $\mathrm{n}^{1}$ & $\mathrm{n}^{2}=23,154$ & $\mathrm{~N}=29,467$ & $\mathrm{n}^{1}$ & $\mathrm{n}^{2}=6,313$ & $\mathrm{~N}=29,467$ & & & & Min & Max \\
\hline 11 & 736 & $3.2 \%$ & $2.5 \%$ & 266 & $4.2 \%$ & $0.9 \%$ & $<0.001$ & $<0.001$ & 0.976 & 0.974 & 0.979 \\
\hline 12 & 737 & $3.2 \%$ & $2.5 \%$ & 271 & $4.3 \%$ & $0.9 \%$ & & & & & \\
\hline 13 & 884 & $3.8 \%$ & $3.0 \%$ & 294 & $4.7 \%$ & $1.0 \%$ & & & & & \\
\hline 14 & 641 & $2.8 \%$ & $2.2 \%$ & 311 & $4.9 \%$ & $1.1 \%$ & & & & & \\
\hline 15 & 620 & $2.7 \%$ & $2.1 \%$ & 329 & $5.2 \%$ & $1.1 \%$ & & & & & \\
\hline 16 & 688 & $3.0 \%$ & $2.3 \%$ & 287 & $4.5 \%$ & $1.0 \%$ & & & & & \\
\hline 17 & 839 & $3.6 \%$ & $2.8 \%$ & 201 & $3.2 \%$ & $0.7 \%$ & & & & & \\
\hline 21 & 760 & $3.3 \%$ & $2.6 \%$ & 268 & $4.2 \%$ & $0.9 \%$ & & & & & \\
\hline 22 & 710 & $3.1 \%$ & $2.4 \%$ & 278 & $4.4 \%$ & $0.9 \%$ & & & & & \\
\hline 23 & 886 & $3.8 \%$ & $3.0 \%$ & 291 & $4.6 \%$ & $1.0 \%$ & & & & & \\
\hline 24 & 660 & $2.9 \%$ & $2.2 \%$ & 308 & $4.9 \%$ & $1.0 \%$ & & & & & \\
\hline 25 & 570 & $2.5 \%$ & $1.9 \%$ & 334 & $5.3 \%$ & $1.1 \%$ & & & & & \\
\hline 26 & 637 & $2.8 \%$ & $2.2 \%$ & 304 & $4.8 \%$ & $1.0 \%$ & & & & & \\
\hline 27 & 829 & $3.6 \%$ & $2.8 \%$ & 226 & $3.6 \%$ & $0.8 \%$ & & & & & \\
\hline 31 & 1,273 & $5.5 \%$ & $4.3 \%$ & 53 & $0.8 \%$ & $0.2 \%$ & & & & & \\
\hline 32 & 1,271 & $5.5 \%$ & $4.3 \%$ & 62 & $1.0 \%$ & $0.2 \%$ & & & & & \\
\hline 33 & 1,243 & $5.4 \%$ & $4.2 \%$ & 105 & $1.7 \%$ & $0.4 \%$ & & & & & \\
\hline 34 & 957 & $4.1 \%$ & $3.2 \%$ & 231 & $3.7 \%$ & $0.8 \%$ & & & & & \\
\hline 35 & 701 & $3.0 \%$ & $2.4 \%$ & 284 & $4.5 \%$ & $1.0 \%$ & & & & & \\
\hline 36 & 386 & $1.7 \%$ & $1.3 \%$ & 199 & $3.2 \%$ & $0.7 \%$ & & & & & \\
\hline 37 & 638 & $2.8 \%$ & $2.2 \%$ & 217 & $3.4 \%$ & $0.7 \%$ & & & & & \\
\hline 41 & 1,269 & $5.5 \%$ & $4.3 \%$ & 52 & $0.8 \%$ & $0.2 \%$ & & & & & \\
\hline 42 & 1,269 & $5.5 \%$ & $4.3 \%$ & 56 & $0.9 \%$ & $0.2 \%$ & & & & & \\
\hline 43 & 1,236 & $5.3 \%$ & $4.2 \%$ & 104 & $1.6 \%$ & $0.4 \%$ & & & & & \\
\hline 44 & 943 & $4.1 \%$ & $3.2 \%$ & 231 & $3.7 \%$ & $0.8 \%$ & & & & & \\
\hline 45 & 697 & $3.0 \%$ & $2.4 \%$ & 289 & $4.6 \%$ & $1.0 \%$ & & & & & \\
\hline 46 & 424 & $1.8 \%$ & $1.4 \%$ & 222 & $3.5 \%$ & $0.8 \%$ & & & & & \\
\hline 47 & 650 & $2.8 \%$ & $2.2 \%$ & 240 & $3.8 \%$ & $0.8 \%$ & & & & & \\
\hline Total & 23,154 & $100.0 \%$ & $78.6 \%$ & 6,313 & $100.0 \%$ & $21.4 \%$ & & & & & \\
\hline
\end{tabular}

$\mathrm{n}^{1}=$ number of each tooth type; $\mathrm{n}^{2}=$ number of teeth without endodontic treatment; $\mathrm{N}=$ total number of teeth; $\mathrm{P} 1=\chi^{2} ; \mathrm{P} 2=$ logistic regression; OR - odds ratio; $\mathrm{Min}=$ minimum; $\mathrm{Max}=$ maximum. 
of root canal treatment according to the tooth type.

Maxillary premolars and molars were the teeth in which endodontic treatment was most frequent, whereas mandibular incisors showed the lowest prevalence. The largest number of endodontic treatments was found among individuals aged 46 to 60 years $(47.6 \%, \mathrm{p}<0.001)$. Females $(61.9 \%, \mathrm{p}<0.001)$ showed the greatest prevalence (Table 1). Interobserver agreement was excellent, and kappa values were greater than 0.91 .

\section{DISCUSSION}

The results of this cross-sectional evaluation are similar to those of previous studies $(5,6,16)$, in which males had significantly fewer remaining natural teeth than females. The average number of root-filled teeth was also lower among males.

The most prevalent teeth were maxillary premolars followed by maxillary molars and mandibular premolars and molars (Table 1). This result is in accordance with those of Lupi-Pegurier et al. (6). Kirkevang et al. (5) found that significantly more molars had been endodontically treated $(8.1 \%)$ than premolars $(5.4 \%)$ or anterior teeth $(2.5 \%)$. This difference may be explained by the number of root-filled teeth in each sample.

The analysis of prevalence of root canal treatment according to age revealed a higher prevalence in the 46-60-year-old range $(n=8,460 ; 47.6 \%)$ and a decrease in subjects older than 60 years $(n=2,680 ; 20.6 \%)$. These values should be analyzed according to sample size and risk of caries disease, which were based on a Brazilian government's study of the oral health of the Brazilian population (3). A substantial increase in the number of dental caries sequelae and lost teeth were found in the groups of individuals aged 35 to 44 and 65 to 74 years.

This cross-sectional study was designed according to the methodologies of previous studies (514). Images of a random sample from a database were examined to calculate the number of endodontically treated teeth. Panoramic radiographs are often used for such purpose in epidemiological studies (6,8-10). LupiPegurier et al. (6) reported that the fact that all teeth can be seen using only one radiograph, the relatively low patient radiation dose, and the convenience and speed with which panoramic radiographs can be obtained are advantages over full-mouth periapical radiographs. Estrela et al. (13) evaluated the periapical status and quality of root canal fillings, suggesting that epidemiological studies to assess the quality of periapical conditions using panoramic or periapical radiographs should be reviewed. Those authors found that CBCT images were more accurate than conventional methods.

In the present study, calibration was good and kappa was greater than 0.91 , which indicates a high interobserver agreement. Studies that used similar methods also found high kappa values $(6,13,16)$.

The high rate of endodontic treatment, a critical sequela of dental caries, points to the negative impact of this important risk factor. The clinical impact of this study reinforces the need for permanent educational programs. The prevalence of endodontically treated teeth in the Brazilian adult population evaluated in the present study was higher than that observed in epidemiological studies conducted in other countries. Females had more endodontically treated teeth than males. Endodontic treatment was most frequent in maxillary premolars and molars. Most endodontically treated teeth were found in 46-60-year-olds (47.6\%) and the prevalence increased with age in this age range.

\section{RESUMO}

O objetivo do estudo transversal foi avaliar a prevalência de dentes tratados endodonticamente em uma população de Brasileiros adultos. Um total de 1.401 radiografias panorâmicas, oriundas do banco de imagens do Centro de Radiologia e Imagens Orofacial de Cuiabá (CRIOF, Cuiabá, MT, Brasil), entre agosto de 2002 e setembro de 2007 foi analisado. Três examinadores avaliaram todas as imagens, considerando-se a presença de tratamento endodôntico, indiferente à qualidade do tratamento (presença ou ausência de retentor intra-radicular ou periodontite apical). Os dados foram estatisticamente avaliados empregandose razão de chances (odds ratio), regressão logística e teste Quiquadrado. A partir de 29.467 dentes avaliados, 6.313 (21,4\%) eram endodonticamente tratados. Os pré-molares e molares superiores foram os dentes com maior prevalência de tratamento, enquanto os incisivos inferiores representaram o grupo de menor prevalência. Indivíduos do gênero feminino $(61,9 \%)$, e com idade entre 46 a 60 anos apresentaram maior prevalência de tratamento endodôntico. O presente estudo encontrou elevada prevalência de dentes tratados endodonticamente em adultos Brasileiros comparada com outros estudos epidemiológicos.

\section{REFERENCES}

1. Holland R, Otoboni-Filho JA, Souza V, Mello W, Nery MJ, Bernabé PFE, et al.. Calcium hydroxide and corticosteroidantibiotic association as dressings in cases of biopulpectomy. A comparative study in dogs teeth. Braz Dent J 1998;9:67- 
76

2. Estrela C, Holland R, Bernabé PFE, Souza V, Estrela CRA. Antimicrobial potential of medicaments used in healing process in dogs teeth with apical periodontitis. Braz Dent $\mathrm{J}$ 2004;15:181-185.

3. Oral Health Project. Ministry of Health. Brazil 2003: oral health conditions of the Brazilian population 2002-2003. Brasília: National Coordination of Oral Health; 2004. 67 p (original document in Portuguese).

4. Eriksen HM, Kirkevang LL, Petersson K. Endodontic epidemiology and treatment outcome: general considerations. Endod Topics 2002;2:1-9.

5. Kirkevang LL, Hørsted-Bindslev P, Ørstavik D, Wenzel A. Frequency and distribution of endodontically treated teeth and apical periodontitis in an urban Danish population. Int Endod J 2001;34:198-205.

6. Lupi-Pegurier L, Bertrand MF, Muller-Bolla M, Rocca JP, Bolla M. Periapical status, prevalence and quality of endodontic treatment in an adult French population. Int Endod $\mathrm{J}$ 2002;35:690-697.

7. Tsuneishi M, Yamamoto $T$, Yamanaka R, Tamaki N, Sakamoto T, Tsuji K, et al.. Radiographic evaluation of periapical status and prevalence of endodontic treatment in an adult Japanese population. Oral Surg Oral Med Oral Pathol Oral Radiol Endod 2005;100:631-635.

8. De Cleen MJH, Schuurs AHB, Wesselink PR, Wu M-K. Periapical status and prevalence of endodontic treatment in an adult Dutch population. Int Endod J 1993;26:112-119.

9. Marques MD, Moreira B, Eriksen HM. Prevalence of. Apical periodontitis and results of endodontic treatment in an adult, Portuguese population. Int Endod J 1998;31:161-165.

10. DeMoor RGJ, Hommez GMG, DeBoever JG, Delme KIM, Martens GEI. Periapical health related to the quality of root canal treatment in a Belgian population. Int Endod $\mathrm{J}$ 2000;33:113-120.

11. Boltacz-Rzepkowska E, Laszkiewicz J. Endodontic treatment and periapical health in patients of the Institute of Dentistry in Lódz. Przegl Epidemiol 2005;59:107-115.
12. Estrela 'C, Leles CR, Hollanda ACB, Moura MS, Pécora JD Prevalence and risk factors of apical periodontitis in endodontically treated teeth in a selected population of Brazilian adults. Braz Dent J 2008;19:34-39.

13. Estrela C, Bueno MR, Leles CR, Azevedo B, Azevedo JR. Accuracy of cone beam computed tomography and panoramic and periapical radiography for detection of apical periodontitis. J Endod 2008;34:273-279.

14. Estrela C, Bueno MR, Azevedo B, Azevedo JR, Pécora JD. A New Periapical Index Based on Cone Beam Computed Tomography. J Endod 2008;34:1325-1331.

15. Jiménez-Pinzón A, Segura-Egea JJ, Poyato-Ferrera $M$, Velasco-Ortega E, Rios-Santos JV. Prevalence of apical periodontitis and frequency of root filled teeth in an adult Spanish population. Int Endod J 2004;37:167-173.

16. Dugas NN, Lawrence HP, Teplitsky PE, Pharoah MJ, Friedman S. Periapical health and treatment quality assessment of root-filled teeth in two Canadian populations. Intern Endod $\mathrm{J}$ 2003;36:181-192.

17. Kirkevang LL, Wenzel A. Risk indicators for apical periodontitis. Community Dent Oral Epidemiol 2003;31:59-67.

18. Buckley $\mathrm{M}$, Spångberg LS. The prevalence and technical quality of endodontic treatment in an American subpopulation. Oral Surg Oral Med Oral Pathol Oral Radiol Endod 1995;79:92-100.

19. Bueno MR, Estrela C. Prevalence of endodontic treatment and apical periodontitis in several populations of world, detected by panoramic and periapical radiography and cone beam computed tomography. Rev Odontol Brasil Central 2008; 17:79-90.

20. Amaral MA, Nakama L, Conrado CA, Matsuo T. Dental caries in young male adults: prevalence, severity and associated factors. Braz Oral Res 2005;19:149-155

Accepted October 24, 2008 